\title{
The effect of temperature and crown size on asparagus yielding
}

\author{
Monika Gasecka ${ }^{1}$, Włodzimierz Krzesiński ${ }^{2}$, Jerzy Stachowiak ${ }^{1}$, \\ Mikołaj Knaflewski \\ Poznań University of Life Sciences, Poland \\ ${ }^{1}$ Department of Chemistry, Wojska Polskiego 75, 60-625 Poznań \\ ${ }^{2}$ Department of Vegetable Crops, Dabrowskiego 159, 60-594 Poznań \\ e-mail:buba@up.poznan.pl
}

Key words: carbohydrates, ferns, spear diameter, spear weight

\begin{abstract}
In order to determine the effect of temperature on asparagus yielding in the case of different crown sizes, asparagus plants were planted in growth chambers, in an aeroponic system with recirculation. The results show that asparagus yield was dependent on air temperature and crown size; however, crown size had a greater influence on the yield. The diameter and weight of the asparagus spears were also dependent on crown size. Higher dry weight content, degrees Brix, fructan and total carbohydrate content in storage roots were documented in large crown asparagus plants before and after harvest. Large sized crowns were also shown to build thicker and higher ferns.
\end{abstract}




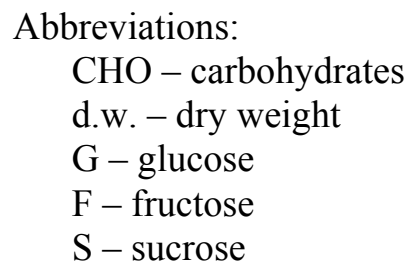

GFS - glucose, fructose, sucrose

\section{INTRODUCTION}

Asparagus yield is the result of photosynthesis and also strongly depends on environmental conditions, cultivation practices, meteorological factors, plant age, asparagus cultivar, the length of harvest, carbohydrates accumulated in storage roots and temperature (Gifford and Evans 1981, Yen et al. 1996, Knaflewski and Kałużewicz 1998, Wilson et al. 1999, Knaflewski and Krzesiński 2002, Paschold et al. 2002, Gąsecka et al. 2008, Krzesiński et al. 2008).

Temperature is the main factor affecting not only the start, but also the end of harvest. The air and soil temperature relationships at the end of dormancy and the beginning of spear growth were described by many authors (Robb 1984, Nichols and Woolley 1985). The temperature threshold for bud break varies with plant age, as older plants produce spears earlier than one- or two-year-old ones (Robb 1984). Changes in temperature during the harvest also have an effect on the dynamics of yielding (Nichols and Woolley 1985, McCormick and Geddes 1996).

The study focused on the determination of a relationship between temperature and asparagus yielding in the case of different crown sizes. The effect of interaction between temperature and crown size on quality and quantity of green spears was also investigated. Additionally, the carbohydrate content in storage roots during the harvest and assimilation periods was documented.

\section{MATERIAL AND METHODS}

The experiment was conducted in a climatic room $\left(10 \mathrm{~m}^{2}\right)$ during three cycles, each consisting of assimilation and harvest seasons. Four-year-old 'Epos' asparagus crowns were planted on the $18^{\text {th }}$ of April 2005 in a growth chamber $\left(250 \mathrm{dm}^{3}\right)$. Eight asparagus plants were planted in an aeroponic system with recirculation. The trial was established using a completely randomized block design with four replications. Green spears $22 \mathrm{~cm}$ in length were collected every day. Nutrition levels were adapted to asparagus requirements based on the analyses of nutrient composition and asparagus plant appearance (Table 1). A nutrient solution was supplied in cycles, with one cycle time of two minutes. The frequency of nutrient 
solution administration depended on the air temperature. At $15^{\circ} \mathrm{C}$ the break between successive cycles was eight minutes, while at $20^{\circ} \mathrm{C}$ it was three minutes and at $25^{\circ} \mathrm{C}$ one minute. The first factor was crown size, while the other was temperature during harvest. The average weight of the large crowns was $3.1 \pm 1.2 \mathrm{~kg}$, while that of smaller ones was $1.3 \pm 0.3 \mathrm{~kg}$. During the first cycle, the temperature at the beginning was about $15^{\circ} \mathrm{C}$, then $20^{\circ} \mathrm{C}$ and at the end $25^{\circ} \mathrm{C}$. During the second cycle temperatures were $20^{\circ} \mathrm{C}, 25^{\circ} \mathrm{C}$ and $15^{\circ} \mathrm{C}$, while during the third cycle $25^{\circ} \mathrm{C}, 15^{\circ} \mathrm{C}$ and $20^{\circ} \mathrm{C}$, respectively. During the assimilation season the temperature was $25^{\circ} \mathrm{C}$.

Table 1. Nutrient composition in asparagus in an aeroponic system

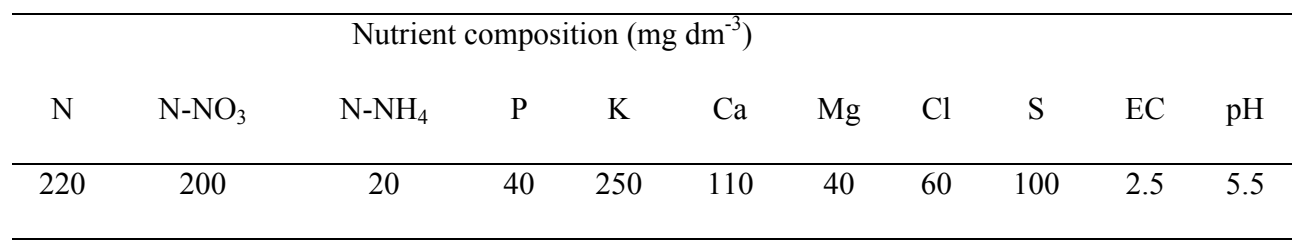

A harvest was not conducted during the first year after planting because of storage root regeneration. During assimilation seasons the humidity was $60-65 \%$. High-pressure sodium lamps (HPS) at photosynthetic photon flux densities (PPFD) of $300 \mu \mathrm{mol} \mathrm{m} \mathrm{m}^{-2} \mathrm{~s}^{-1}$ were used to provide an $18 \mathrm{~h}$ day.

Two weeks before the end of the assimilation, the seasonal air temperature was successfully decreased to $5^{\circ} \mathrm{C}$ and the frequency of watering was reduced. Ferns after senescence were cut off. Air temperature and the frequency of nutrient solution application were increased to start the harvest.

Harvest durations lasted about 33 days (on average 11 days for each temperature variant), while assimilation seasons were about 107 days long. Growing buds on crowns built ferns, starting a new cycle.

\section{Extraction and carbohydrate analysis}

Samples of approximately $2000 \mathrm{mg}$ of fleshy storage root each were subjected to extraction for 60 minutes with $10 \mathrm{ml}$ of $80 \%$ ethanol at $80^{\circ} \mathrm{C}$ (Johansen et al. 1996). Soluble sugars were analysed by HPLC (Waters Alliance 2695) using a Sugar-Pak I column (Waters) and RI detector (Waters 2414). The mobile phase (filtered water with $0.1 \mathrm{mM}$ Ca EDTA) was pumped through the column at a flow rate of $0.4 \mathrm{ml} \mathrm{min}^{-1}$. The temperature of the column was $70^{\circ} \mathrm{C}$, while that of the detector $40^{\circ} \mathrm{C}$. Sucrose, glucose and fructose were identified by their retention times (14.4, 12.0 and $9.8 \mathrm{~min}$., respectively) and were quantified according to standards. 
Total sugars were determined in the same extract after hydrolysis with $18 \%$ $\mathrm{HCl}$ for $24 \mathrm{~h}$ at room temperature (Siomos and Pontikidou 2000). Fructan content was calculated based on the difference between total carbohydrate content and GFS.

\section{Statistical analysis}

To evaluate the significance of differences between the treatments, a two-factorial analysis of variance was used. The means were separated by the Newman-Keuls test at $p=0.05$. The regression equations and their coefficients were estimated by the computer programs TableCurve 2D and TableCurve 3D SPSS Inc. The equations were fitted by standard least-squares minimisation. Based on the results obtained from the program the power function was chosen.

\section{RESULTS AND DISCUSSION}

The experiment determined that large crown asparagus plants had significantly higher dry weight, degrees Brix, and fructan and total carbohydrate content in their roots than small crown plants before and after harvest (Table 2). This resulted in a high yield potential of large crown asparagus plants. A decrease in fructose and GFS content in the asparagus roots after harvest was reported. This fluctuation was most likely related to the high demand of this sugar during the dynamic growth of the shoots. Decreases in dry weight, degrees Brix and soluble sugar content were not significant. During three harvest cycles, a $98 \mathrm{~g}$ total carbohydrate loss was confirmed in the large crowns, while only a $35 \mathrm{~g}$ loss was recorded in the small crowns, the result being statistically significant. This was probably a consequence of the carbohydrates being used for spear growth. As it was confirmed, for example in Holland, in a $10 \mathrm{t} \mathrm{ha}^{-1}$ yield with a mean solid content of $4.5 \%$ Brix in the spears, a $450 \mathrm{~kg}$ carbohydrates loss was found in the harvested spears (Teeuwen 2005).

Before and after the assimilation season, the plants with large crowns contained higher amounts of dry weight, degrees Brix, sugars (besides glucose and fructose) and total carbohydrates than plants with small crowns (Table 3). After assimilation a loss of dry weight was observed both in small and large crowns, connected with their high demand in the phase of fern formation. In contrast, an increase in glucose, fructose and sucrose contents in storage roots was in all probability connected with photosynthesis and the transfer of assimilates to storage organs. Changes in sugars, dry weight content and degrees Brix were not dependent on the crown size (Table 3). During the assimilation period both air temperature and temperature near the crown were $25^{\circ} \mathrm{C}$. Because of this fact, carbohydrates were probably not stored, but they were used during respiration. 
Table 2. Average dry weight, content of solids and carbohydrates in storage roots of asparagus before and after harvest; three cycles at different temperatures in a growth chamber in $2005-2006$

\begin{tabular}{|c|c|c|c|c|c|c|c|c|c|c|}
\hline \multirow[t]{2}{*}{ Term } & \multirow[t]{2}{*}{$\begin{array}{c}\text { Crown } \\
\text { size }\end{array}$} & $\begin{array}{l}\frac{\overrightarrow{0}}{50} \\
.000 \\
03 \\
3 \\
0 \\
0\end{array}$ & $\stackrel{x}{\ddot{n}}$ & $\begin{array}{l}\underset{0}{0} \\
0 \\
0 \\
0 \\
\Xi \\
0\end{array}$ & $\begin{array}{l}\text { 至 } \\
0 \\
0 \\
\stackrel{0}{0} \\
\text { 岂 }\end{array}$ & 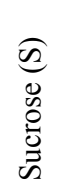 & 壳 & 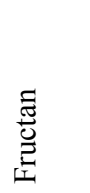 & 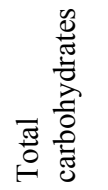 & 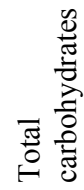 \\
\hline & & \multicolumn{3}{|c|}{$(\%)$} & \multicolumn{3}{|c|}{ (mg g ${ }^{-1}$ d.w.) } & \multicolumn{3}{|c|}{$\left(\right.$ g plant $\left.^{-1}\right)$} \\
\hline \multirow{2}{*}{$\begin{array}{l}\text { Before } \\
\text { harvest (A) }\end{array}$} & Large & $20.1^{*}$ & $16.0^{*}$ & 39.4 & 14.8 & 6.8 & 61 & $365^{*}$ & $426^{*}$ & $238^{*}$ \\
\hline & Small & 17.8 & 12.1 & 48.4 & 15.6 & 5.3 & 69 & 263 & 332 & 89 \\
\hline \multirow{3}{*}{$\begin{array}{l}\text { After } \\
\text { harvest (B) }\end{array}$} & Large & $16.1^{*}$ & $9.3^{*}$ & 4.3 & $22.1^{*}$ & 4.8 & $31^{*}$ & $356^{*}$ & $387^{*}$ & $140^{*}$ \\
\hline & Small & 14.5 & 7.1 & 10.3 & 27.2 & 9.4 & 47 & 205 & 252 & 54 \\
\hline & Large & -4.0 & -6.7 & -35.1 & +7.3 & -2.0 & -30 & -9 & -39 & $-98^{*}$ \\
\hline B-A & Small & -3.3 & -5.0 & -38.2 & +11.5 & 4.1 & -23 & -58 & -80 & -35 \\
\hline
\end{tabular}

*significant at $\mathrm{p}=0.05$

Table 3. Average dry weight, content of solids and carbohydrates in storage roots of asparagus before and after assimilation season; three cycles at different temperatures in a growth chamber in $2005-$ 2006

\begin{tabular}{|c|c|c|c|c|c|c|c|c|c|c|}
\hline \multirow[t]{2}{*}{ Term } & \multirow[t]{2}{*}{$\begin{array}{l}\text { Crown } \\
\text { size }\end{array}$} & $\begin{array}{l}\overrightarrow{\vec{E}} \\
\frac{000}{0} \\
3 \\
\overrightarrow{0} \\
\overrightarrow{0}\end{array}$ & 层 & $\begin{array}{l}\text { (0) } \\
0 \\
0 \\
0 \\
0 \\
0 \\
0\end{array}$ & 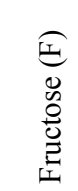 & $\begin{array}{l}\widetilde{D} \\
0 \\
0 \\
0 \\
0 \\
0 \\
\overrightarrow{0}\end{array}$ & $\begin{array}{l}\text { N } \\
\text { 峲 }\end{array}$ & 志 & 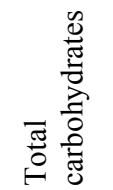 & 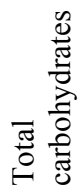 \\
\hline & & & $(\%)$ & & \multicolumn{3}{|c|}{ (mg g ${ }^{-1}$ d.w.) } & \multicolumn{3}{|c|}{$\left(\right.$ g plant $\left.^{-1}\right)$} \\
\hline \multirow{2}{*}{$\begin{array}{l}\text { Before } \\
\text { harvest (A) }\end{array}$} & Large & $20.8^{*}$ & $18.0^{*}$ & 17.2 & 12.7 & $5.6^{*}$ & $35^{*}$ & $486^{*}$ & $521 *$ & $289 *$ \\
\hline & Small & 18.4 & 12.9 & 25.3 & 17.4 & 13.8 & 57 & 300 & 356 & 108 \\
\hline \multirow{2}{*}{$\begin{array}{l}\text { After } \\
\text { harvest (B) }\end{array}$} & Large & $19.4^{*}$ & $14.8^{*}$ & 68.4 & 15.0 & $18.5^{*}$ & 102 & $295^{*}$ & $397^{*}$ & $220 *$ \\
\hline & Small & 17.5 & 11.7 & 102.1 & 16.6 & 12.8 & 132 & 191 & 323 & 91 \\
\hline \multirow{2}{*}{ B-A } & Large & -1.4 & -3.2 & 51.3 & 2.3 & 12.9 & 66 & -191 & -124 & -69 \\
\hline & Small & -0.9 & -1.1 & 76.8 & -0.8 & -1.0 & 75 & -118 & -34 & -18 \\
\hline
\end{tabular}

*significant at $p=0.05$ 
The investigation determined that average yields from three cycles were dependent on air temperature and crown size (Table 4). The highest yields were harvested from plants with large crowns at $25^{\circ} \mathrm{C}$. The crown size had a stronger influence on yield than temperature (described by $\mathrm{F}_{\mathrm{emp}}$ ). The yield from large crowns was generally 2.5 times higher than from small crowns. High plant yield potential was probably the result of crown size, the quantity and quality of asparagus buds and carbohydrates stored in roots. Before the harvest, large asparagus crowns stored $238 \mathrm{~g}$ of carbohydrates per plant, while small ones only 89 g per plant. Similar results were reported by Woolley et al. (1996). However, there are no experiments that document the relationship between temperature and crown size. In the following paper the interactions between crown size and air temperature were not significant for yield. Our results showed that the higher the temperature, the bigger the yield. It was 2.8 times higher at $25^{\circ} \mathrm{C}$ than at $15^{\circ} \mathrm{C}$. Moreover, the effect of temperature and carbohydrate amounts in storage roots explained $51 \%$ of the total variation in the daily yield (Fig. 1).

Table 4. Average spear yield $\left(\mathrm{g} \mathrm{plant}^{-1}\right)$ harvested from small and large asparagus crowns grown in three cycles at different temperatures in a growth chamber in $2005-2006$

\begin{tabular}{lcrcc}
\hline Crown size & \multicolumn{3}{c}{ Temperature } \\
$20^{\circ} \mathrm{C}$ & $25^{\circ} \mathrm{C}$ & Average \\
\hline Small & 12.7 & 19.1 & 36.7 & 22.8 \\
Large & 31.2 & 51.9 & 85.1 & 56.1 \\
Average & 22.0 & 35.5 & 60.9 & \\
\hline Parameter & Crown size (A) & Temperature (B) & $\mathrm{A} \times \mathrm{B}$ \\
$\mathrm{F}_{\text {emp }}$ & & $9.24^{* *}$ & $4.36^{*}$ & 0.62 \\
LSD $_{0.05}$ & & 22.2 & 27.2 & n.s.
\end{tabular}

*significant at $\mathrm{p}=0.05, * *$ significant at $\mathrm{p}=0.01$

The number of harvested spears depended on the temperature (Table 5). At $25^{\circ} \mathrm{C}$ the number of harvested spears was significantly greater than at $15^{\circ} \mathrm{C}$ and $20^{\circ} \mathrm{C}$. The effect of crown size on spear number was not significant. It was found that the power function describing the number of harvested spears in dependence of temperature explained a $39 \%$ variation in the number of spears (Fig. 2).

Both the diameter and average weight of the spears were crown size dependent (Tables 6 and 7). However, the visible effect of crown size on yield was not significant. The average diameter of harvested spears was $1 \mathrm{~mm}$ and their average weight was $1.3 \mathrm{~g}$ greater in large crown asparagus plants, respectively. The temperature influence and interactions between temperature and crown size were not significant for the diameter of spears and their average weight. However, Poll (1996) reported that an air temperature increase caused a decrease of average spear 
weight. McCormic and Geddes (1996) documented similar results when investigating a relationship between low temperature and spear growth. The spears in our experiment were thin, probably because air temperature and temperature near the crown were the same $\left(25^{\circ} \mathrm{C}\right)$, while in field conditions the temperature near the crown was $15^{\circ} \mathrm{C}$ during the harvest.

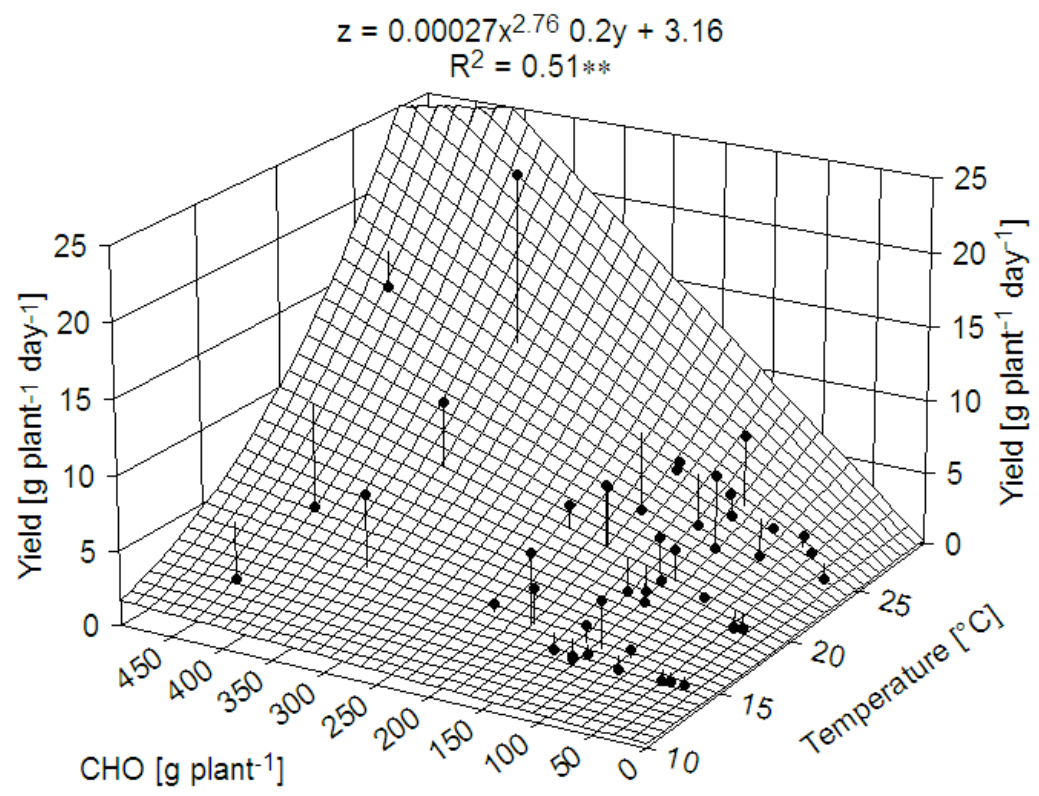

*significant at $\mathrm{p}=0.01$

Fig. 1. The effect of temperature and amount of carbohydrates on daily asparagus yield per plant

Table 5. Average number of spears per plant harvested from small and large asparagus crowns grown in three cycles at different temperatures in a growth chamber in $2005-2006$

\begin{tabular}{lcccc}
\hline Crown size & \multicolumn{1}{c}{ Temperature } \\
$20^{\circ} \mathrm{C}$ & 4.0 & $25^{\circ} \mathrm{C}$ & Average \\
\hline Small & 2.7 & 9.7 & 17.2 & 8.0 \\
Large & 5.3 & 6.8 & 24.8 & 13.2 \\
Average & 4.0 & 21.0 & \\
\hline Parametr & Crown size (A) & Temperature (B) & \multicolumn{2}{c}{$\mathrm{A} \times \mathrm{B}$} \\
$\mathrm{F}_{\text {emp }}$ & 2.10 & $8.45^{* *}$ & & 0.17 \\
LSD $_{0.05}$ & n.s. & 9.0 & & n.s. \\
\hline
\end{tabular}

** significant at $\mathrm{p}=0.01$ 
The number of ferns was dependent on plant age (Krzesiński et at. 2008). During the experiment the crown size effect on asparagus ferns was analysed large sized crowns were documented to form thicker and higher ferns (Table 8). This was probably connected to the stored carbohydrate content in the roots and their dry weight (Table 2).

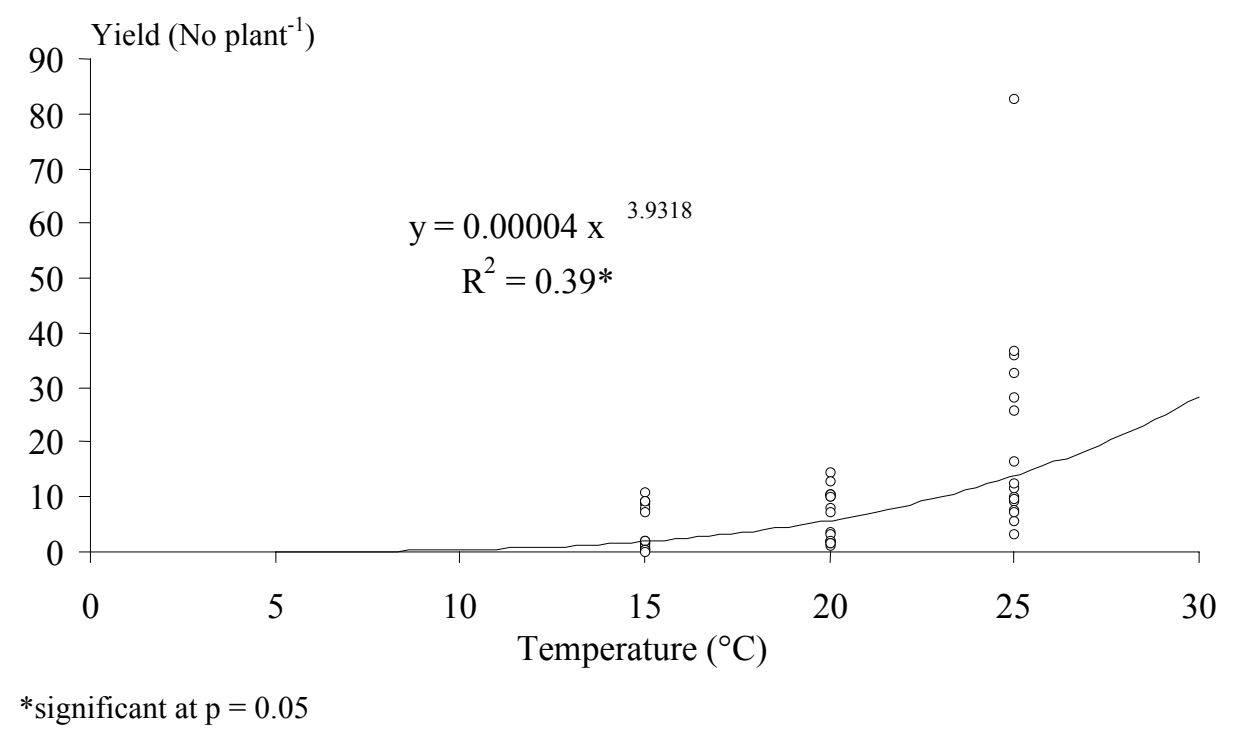

Fig. 2. The effect of temperature on average number of spears per plant

Table 6. Average diameter $(\mathrm{mm})$ of spears harvested from small and large asparagus crowns grown in three cycles at different temperatures in a growth chamber in $2005-2006$

\begin{tabular}{lcccc}
\hline Crown size & $15^{\circ} \mathrm{C}$ & $\begin{array}{c}\text { Temperature } \\
20^{\circ} \mathrm{C}\end{array}$ & $25^{\circ} \mathrm{C}$ & Average \\
\hline Small & 4.3 & 4.6 & 3.7 & 4.2 \\
Large & 5.2 & 5.2 & 4.9 & 5.1 \\
Average & 4.7 & 4.9 & 4.3 & \\
\hline Parameter & Crown size (A) & Temperature (B) & \multicolumn{2}{c}{$\mathrm{A} \times \mathrm{B}$} \\
$\mathrm{F}_{\text {emp }}$ & $14.56^{* *}$ & 2.38 & \multicolumn{2}{c}{0.46} \\
LSD $_{0.05}$ & 0.50 & n.s. & n.s. & \\
\hline
\end{tabular}

** significant at $\mathrm{p}=0.01$ 
Table 7. Average weight $(\mathrm{g})$ of spears harvested from small and large asparagus crowns grown in three cycles at different temperatures in a growth chamber in $2005-2006$

\begin{tabular}{lcccc}
\hline Crown size & $15^{\circ} \mathrm{C}$ & $\begin{array}{c}\text { Temperature } \\
20^{\circ} \mathrm{C}\end{array}$ & $25^{\circ} \mathrm{C}$ & Average \\
\hline Small & 3.3 & 3.7 & 2.4 & 3.1 \\
Large & 4.5 & 4.7 & 3.9 & 4.4 \\
Average & 3.9 & 4.2 & 3.2 & $\mathrm{~A} \times \mathrm{B}$ \\
\hline Parameter & Crown size (A) & Temperature (B) & & 0.19 \\
$\mathrm{~F}_{\text {emp }}$ & $10.24^{* *}$ & 2.65 & & n.s. \\
LSD $_{0.05}$ & 0.79 & n.s. & & \\
\hline
\end{tabular}

** significant at $\mathrm{p}=0.01$

Table 8. The effect of crown size on the size of asparagus ferns

\begin{tabular}{lccccc}
\hline $\begin{array}{l}\text { Crown } \\
\text { size }\end{array}$ & $\begin{array}{c}\text { Diameter } \\
(\mathrm{mm})\end{array}$ & $\begin{array}{c}\text { Length } \\
(\mathrm{cm})\end{array}$ & Shoot number & $\begin{array}{c}\text { One shoot weight } \\
(\mathrm{g})\end{array}$ & $\begin{array}{c}\text { All shoots weight } \\
(\mathrm{g})\end{array}$ \\
\hline Large & $4.8^{*}$ & $117.3^{*}$ & $15.7^{*}$ & $22.8^{*}$ & $337.6^{*}$ \\
Small & 3.7 & 84.3 & 9.8 & 10.8 & 124.8 \\
\hline $\mathrm{F}_{\mathrm{emp}}$ & $6.68^{*}$ & $11.66^{* *}$ & $6.55^{*}$ & $21.73^{* *}$ & $27.10^{* *}$ \\
$\mathrm{LSD}_{0.05}$ & 0.96 & 20.61 & 4.92 & 5.52 & 87.10 \\
\hline
\end{tabular}

*significant at $\mathrm{p}=0.05, * *$ significant at $\mathrm{p}=0.01$

\section{CONCLUSIONS}

1. Asparagus yield was dependent on temperature and crown size. The crown size had a stronger influence on yield than temperature.

2. Temperature was positively correlated with yield and the number of asparagus spears, while crown size was correlated with yield, diameter and weight of spears.

3. Diameter, length, number and weight of asparagus ferns were crown size dependent.

The studies were financed by the Ministry of Science and Informatics in Warsaw, Project No 2 PO6R 03626. 


\section{REFERENCES}

Gąsecka M., Stachowiak J., KRZesińsKi W., KNAFlewsKi M., GolińsKi P., 2008. Changes in glucose, fructose and sucrose contents in storage roots of asparagus during vegetation period. Veg. Crops Res. Bull. 69: 145-154.

GIFFORD R.M., Evans L.T., 1981. Photosynthesis, carbon partitioning and yield. Ann. Rev. Plant Physiol. 32: 485-509.

Johansen H.N., GLitso V., KNUTSEN K.E.B., 1996. Influence of extraction solvent and temperature on the quantitative determination of oligosaccharides from plant materials by high-performance liquid chromatography. J. Agric. Food Chem. 44: 1470-1474.

KNAFLEWSKI M., KAŁUŻEWICZ A., 1998. Wczesność i dynamika plonowania odmian szparaga w uprawie na zielone wypustki. Zesz. Nauk. ATR Bydgoszcz 215(42): 103-106.

KNAFLEWSKI M., KRZESIŃSKI W., 2002. Results of investigations on timing asparagus production in a temperature climate. Acta Hort. 580: 73-79.

KRZESIŃSKI W., GĄSECKA M., StACHOWIAK J., KNAFLEWSKI M., 2008. Plant age effect on asparagus yielding in terms of carbohydrate balance. Folia Hort. 20(2): 29-38.

MCCORMICK S.J., GEDDES B., 1996. Effect of production temperature on the quantity and quality of green asparagus spears. Acta Hort. 415: 263-269.

NiCHOLS M.A., WoOLEY D.J., 1985. Growth studies with asparagus. In: E.C. Lougheed and H. Tiessen (eds), "Proc. $6^{\text {th }}$ Int. Aspar. Symp.", Univ. Guelph Press, Guelph, Ontario, Canada: 287-297.

PASCHOLD P.J., ARTLET B., HeRMANN G., 2002. Influence of harvest duration on yield and quality of asparagus (Asparagus officinalis L.). Acta Hort. 589: 6571.

POLL J., 1996. The effect of temperature on growth and fibrousness of green asparagus. Acta Hort. 415: 183-185.

RoBB A.R., 1984. Physiology of asparagus (Asparagus officinalis) as related to the production of the crop. N. Z. J. Exp. Agric. 12: 251-260.

SiOMOs A.S., PONTIKIDOU D.G., 2000. Seasonal changes of dry matter and sugars in the fleshy roots of asparagus seedlings. J. Veg. Crop Prod. 6(1): 45-52.

TEEUWEN M.W.T., 2005. A practical view on plant physiology of asparagus. In: " $11^{\text {th }}$ Int. Aspar. Symp., Program and Abstract". June $16^{\text {th }}-$ June $19^{\text {th }}$, Horst, The Netherlands: 45. 
WILSON D.R., SinTON S.M., WRIGHT C.E., 1999. Influence of time of spears harvest on root system resources during the annual growth cycle of asparagus. Acta Hort. 479: 313-320.

Wooley D.J., SudjatMiko S., Yen Y.F., Fisher K.J., Nichols M.A., 1996. Carbon dioxide exchange characteristics and relative growth rates of asparagus cultivars in relation to temperature. Acta Hort. 415: 201-207.

YeN Y.F., NichOls M.A., WoOLEY D.J., 1996. Growth of asparagus spears and ferns at high temperatures. Acta Hort. 415: 163-174.

\section{WPŁYW TEMPERATURY I WIELKOŚCI KARPY NA PLONOWANIE SZPARAGA}

Streszczenie: W celu określenia wpływu temperatury na plonowanie szparaga, z uwzględnieniem wielkości karp, rośliny szparaga uprawiane były metodą aeroponiczną w układzie zamkniętym z recyrkulacją pożywki. Wykazano, że plon szparaga zależał od temperatury powietrza i wielkości karpy, jednak wpływ wielkości karpy na plon był wyraźniejszy. Również średnica i masa wypustek były zależne od wielkości karpy. Wyższą zawartość suchej masy, ekstraktu, fruktanów oraz cukrów ogółem przed i po zbiorach stwierdzono w korzeniach roślin o większych karpach. Wykazano również, że rośliny o dużych karpach tworzyły grubsze i wyższe pędy asymilacyjne. 